\title{
Transmembrane Signalling Operated at Rice Blade Cells Stimulated by Blast Fungus Elicitor II. Participation of Calcium Modulated Protein*1
}

\author{
Hiromasa KanoH, ${ }^{* 2}$ Minoru Haga and Yasuharu Sekizawa*3 \\ Department of Agricultural Chemistry, Faculty of Agriculture, Tamagawa University, \\ Tamagawa-gakuen, Machida 194, Japan
}

(Received February 8, 1993; Accepted May 7, 1993)

\begin{abstract}
The effects of molecular probes on the dynamic behaviours of $\mathrm{O}_{\dot{2}}^{-}$generation and $\alpha$ linolenate release from rice (Oryza sativa) blade tissue preparations with press-injured spot $(2 \mathrm{~mm})$, pre-treated with the molecular probes and post-stimulated with blast fungus (Pyricularia oryzae) elicitor, were further surveyed. Compound W-7 or ophiobolin A, potent inhibitors on the function of CaM (calmodulin), strongly inhibited both $\mathrm{O}_{\dot{2}}^{-}$generation at $10 \mu \mathrm{M}$ and $\alpha$-linolenate release at $500 \mu \mathrm{M}$ after the elicitor stimulation. The comparative coupledenzymic analysis on the behaviour of free CaM in the healthy or infected rice blades with blast fungus conidia revealed an immediate decrease of free CaM by the infection. TPA (10 $\mu \mathrm{M})$, an agonist of diacylglycerol for proteinkinase $\mathrm{C}$, did not activate both parameters with the elicitor stimulation, although TPA $(10 \mu \mathrm{M})$ markedly activated the $\alpha$-linolenate release at the later phase with the stimulation. The application of $\mathrm{H}-7(1 \mathrm{mM})$ or staurosporin $(10 \mu \mathrm{M})$, unspecific inhibitors on proteinkinases, inhibited the $\mathrm{O}_{\dot{2}}^{-}$generation, but staurosporin $(50 \mu \mathrm{M})$ activated the $\alpha$-linolenate release at the later phase and H-7 (1 mM) inhibited the $\alpha$-linolenate release after the elicitor stimulation. The application of 1,2-benzisothiazol-3(2H)-one 1,1dioxide $(1 \mathrm{~mm})$ with the elicitor stimulation further activated the $\mathrm{O}_{\dot{2}}^{-}$generation and markedly activated the $\alpha$-linolenate release at the later phase. The lines of evidence strongly bore out the suggestion that the formations of $\mathrm{Ca}^{2+} \mathrm{MPs}\left(\mathrm{Ca}^{2+}\right.$-calcium modulated proteins), which signal-coupled with the operation of phospholipase $\mathrm{C}$ system, play an indispensable role in activating rice blade $\mathrm{O}_{\dot{2}}^{-}$forming redox system and phospholipase $\mathrm{A}_{2}$.
\end{abstract}

\section{INTRODUCTION}

In the previous paper, ${ }^{1)}$ it was postulated that the signal-activated phospholipase $\mathrm{C}$ system as a transmembrane signalling system

*1 Causal Analysis of Reaction Cascades in the Induced Defense Mechanisms of Rice Plants (Part XIII). For Part XII, see Ref. 1).

The outline of this work was given at the Annual Meeting of Pesticide Science Society of Japan, Machida, Tokyo, March 1990.

*2 Present address: Yokohama Research Center, Chisso Corp., Kanazawa-ku, Yokohama 236, Japan.

*3 To whom correspondence should be addressed. is operating at rice (Oryza sativa) blade cells stimulated by blast fungus (Pyricularia oryzae) elicitor, and that the $\mathrm{O}_{\dot{2}}^{-}$generation and $\alpha$-linolenate release, the two earlier biochemical events activated by the elicitor stimulation, reveal a strong dependency on the mobilization of $\mathrm{Ca}^{2+}$ from $\mathrm{Ca}^{2+}$ stores by $\mathrm{IP}_{3}$ (inositol 1,4,5-trisphosphate). It has been established in animal cells that diacylglycerol, one of the products from plasma membrane $\mathrm{PIP}_{2}$ (phosphatidylinositol 4,5-bisphosphate) by the signal-activated phospholipase $\mathrm{C}$, plays an indispensable role in activating proteinkinase $\mathrm{C}$ as an agonist of $\mathrm{Ca}^{2+}$ and that the phosphorylation of proteinic regulatory factors by proteinkinase 
$\mathrm{C}$ activates $\mathrm{O}_{\dot{i}}^{-}$forming redox system and phospholipase $\mathrm{A}_{2 .} .^{2-5)}$ In this study, we attempted to survey the relationships between $\mathrm{Ca}^{2+}$ as a second messenger and the two parameters, $\mathrm{O}_{i}^{-}$generation and $\alpha$-linolenate release from rice blade tissue stimulated by blast fungus elicitor, using several molecular probes as in the previous paper. ${ }^{1)}$

\section{MATERIALS AND METHODS}

\section{Reagents}

W-7; $N$ - (6 -aminohexyl) - 5 - chloro - 1 - naphthalenesulfonamide $\mathrm{HCl}$, ophiobolin $\mathrm{A}$ and staurosporine were purchased from Sigma. TPA; $12-O$-tetradecanoylphorbol-13-acetate, was purchased from LC Services Co./Funakoshi Chemical Co., Ltd. (Tokyo). H-7; 1-(5-isoquinolinesulfonyl)-2-methylpiperazine $2 \mathrm{HCl}$ was purchased from Seikagaku Kogyo Corp. (Tokyo). CaM (calmodulin) dependent phosphodiesterase (bovine heart muscle), alkaline phosphatase (calf intestine), adenosine deaminase (calf intestine), authentic $\mathrm{CaM}$ (porcine brain) and cyclic adenosine- $3^{\prime}, 5^{\prime}$ monophosphate were purchased from Boehringer Mannheim Yamanouchi Co., Ltd. (Tokyo). $\mathrm{SAC} \cdot \mathrm{Na}$ (1,2-benzisothiazol-3(2H)-one 1,1dioxide sodium salt) was obtained from Wakojunyaku Co., Ltd. (Tokyo). Other reagents used were the highest grade commercially available.

\section{Plant Material and Blast Fungus Elicitor}

Those were the same as described in the previous paper. ${ }^{1)}$

\section{Application of Chemicals, Stimulation by Blast Fungus Elicitor and Determination of $\mathrm{O}_{\dot{2}}^{-}$Generation and $\alpha$-Linolenate Release}

Those were also the same as described in the previous paper. ${ }^{1)}$ The aqueous solution of staurosporine was prepared by diluting $20 \mathrm{~mm}$ staurosporine dimethylsulfoxide solution with deionized water. The application of $0.5 \%$ dimethylsulfoxide aqueous solution $(5 \mu \mathrm{l})$ onto the $2 \mathrm{~mm}$ press-injured spot did not interfere with the both parameters. The aqueous solution of TPA was prepared by diluting $10 \mathrm{~mm}$ TPA ethanol solution with deionized water. The aqueous solution of ophiobolin A was prepared by diluting $50 \mathrm{~mm}$ ophiobolin A ethanol solution with deionized water. The application of $1 \%$ ethanol aqueous solution (5 ul) onto a $2 \mathrm{~mm}$ press-injured spot did not interfere with the both parameters.

\section{Determination of CaM in Rice Blade}

Rice seedlings at four-leaf stage were inoculated by spraying of blast fungus conidial suspension $\left(3 \times 10^{5}\right.$ conidia $\left./ \mathrm{ml}\right)$ for the infected run, and were sprayed with sterile water for control run. The sample was respectively taken in time-course schedule. The total $\mathrm{CaM}$ was extracted in the presence of $5 \mathrm{~mm}$ EDTA and $5 \mathrm{~mm}$ EGTA to dissociate complexes of $\mathrm{Ca}^{2+}-\mathrm{CaM}$ and proteins using $50 \mathrm{~mm}$ Tris- $\mathrm{HCl}$ buffer solution ( $\mathrm{pH} 7.5)$ under homogenizing with Biotron (BT 10/20-3500, Switzerland). The free CaM was extracted in the absence of EDTA and EGTA using the same buffer under homogenizing. After the removal of accompanied proteins by treatment with $5 \%$ trichloroacetic acid ${ }^{6)}$ and Bond Elut DEAE cartrige (Analitychem International Co.), CaM was quantitatively determined by coupled-enzymic assay using $\mathrm{CaM}$ dependent phosphodiesterase (bovine heart muscle). ${ }^{7)}$ The coupled-enzymic assay system consisted of three species of enzymes, $\mathrm{CaM}$ dependent phosphodiesterase, alkaline phosphatase and adenosine deaminase. And the decrease of absorbance at $265 \mathrm{~nm}$, which corresponded to the decrease of adenosine, was consistent with phosphodiesterase activity depending on the amount of CaM. The amount of rice blade $\mathrm{CaM}$, equal to $1 \mu \mathrm{g}$ of the authentic $\mathrm{CaM}$, was defined to 1 unit.

\section{RESULTS}

\section{Effects of $W-7$ and Ophiobolin $A$ on Both of the Parameters}

The effects of W-7 or ophiobolin A, inhibitors on the function of $\mathrm{CaM},{ }^{8-10)}$ on both the parameters, $\mathrm{O}_{\dot{i}}^{-}$generation and $\alpha$-linolenate release, are respectively shown in Figs. 1 and 2. It was observed that $\mathrm{W}-7 \quad(10 \mu \mathrm{M})$ and ophiobolin A $(10 \mu \mathrm{M})$ strongly inhibited the $\mathrm{O}_{\dot{i}}^{-}$generation after the elicitor stimulation and that W-7 $(500 \mu \mathrm{M})$ and ophiobolin A $(500 \mu \mathrm{M})$ inhibited the $\alpha$-linolenate release after the elicitor stimulation. It was noted that the signal-coupled activation of $\mathrm{O}_{2}^{-}$forming redox 

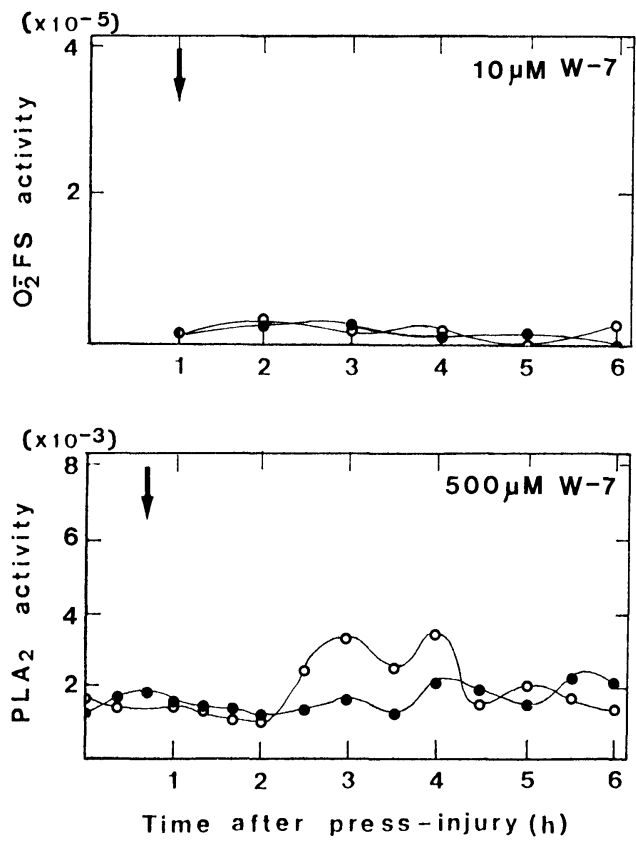

Fig. 1 Effects of $\mathrm{W}-7$ on $\mathrm{O}_{\dot{2}}^{-}$generation and $\alpha$ linolenate release from $2 \mathrm{~mm}$ press-injured rice blade tissue stimulated by blast fungus elicitor.

$\mathrm{O}_{\dot{2}}^{-}$FS activity; activity of $\mathrm{O}_{\dot{2}}^{-}$forming redox system in terms of O.D.560 $\mathrm{nm} \cdot \mathrm{ml}^{-1} \cdot \mathrm{min}^{-1} \cdot \mathrm{mg}$ fresh weight ${ }^{-1}$. $\mathrm{PLA}_{2}$ activity; activity of phospholipase $\mathrm{A}_{2}$ in terms of relative fluorescence intensity at $540 \mathrm{~nm} \cdot \mathrm{min}^{-1} \cdot \mathrm{mg}$ fresh weight ${ }^{-1}$. Refer to the previous report ${ }^{1)}$ regarding the details of determinations on two parameters and control runs without the application of chemical. ○: $2 \mathrm{~mm}$ press-injury with application of $5 \mu \mathrm{l}$ of $10 \mu \mathrm{M}$ or $500 \mu \mathrm{M} \mathrm{W}-7$ (control), $\bullet$ : application of $\mathrm{W}-7$ and additional stimulation by blast fungus elicitor. The arrow indicates the time of stimulation. The similar patterns were observed in duplicated measurements.

system was more sensitive to both $\mathrm{W}-7$ and ophiobolin A than the activation of phospholipase $\mathrm{A}_{2}$.

\section{Dynamic Behaviour of CaM in Rice Blade Tissue Infected by Blast Fungus Conidia}

The content of total CaM in healthy or infected rice blades was approximately 0.4 units/g fresh weight, and did not respectively undergo an appreciable change by the infection in time-course experiments (data not shown). It seemed likely that the contents of
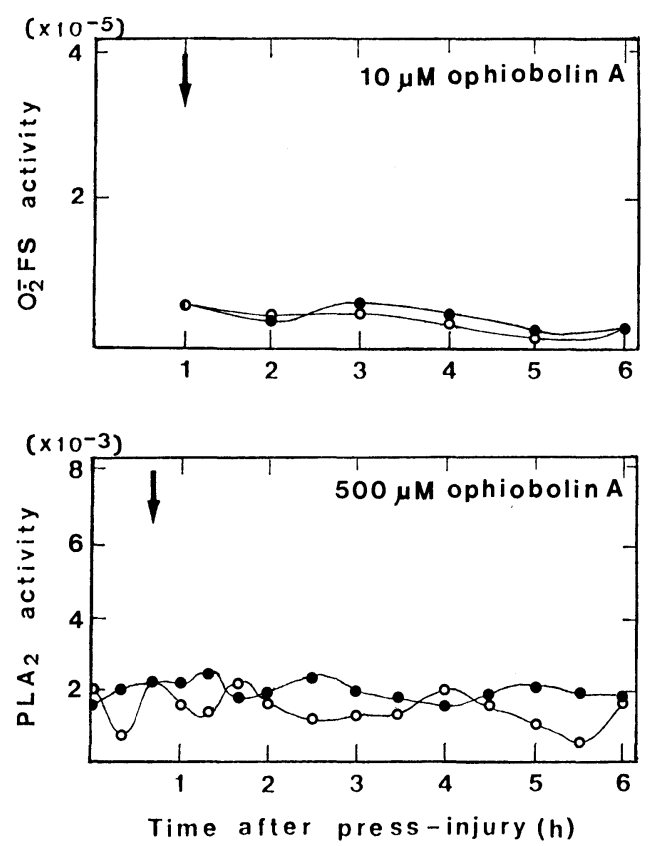

Fig. 2 Effects of ophiobolin $\mathrm{A}^{-}$on $\mathrm{O}_{\dot{2}}^{-}$generation and $\alpha$-linolenate release from the press-injured rice blade tissue.

०: $2 \mathrm{~mm}$ press-injury with application of $5 \mu 1$ of $10 \mu \mathrm{M}$ or $500 \mu \mathrm{M}$ ophiobolin A (control), 0 : application of ophiobolin $\mathrm{A}$ and additional stimulation by blast fungus elicitor. The arrow indicates the time of stimulation. The similar patterns were also observed in duplicated measurements.

total $\mathrm{CaM}$ in rice blade tissue might be lesser than in other plants and animal tissues. It has been reported that the content is about 4 units/g in spinach leaf tissue ${ }^{11)}$ and $400-600$ units/g in rat brain tissue. ${ }^{12}$ The dynamic behaviour of free CaM in healthy or infected rice blade with a compatible race (HOKU $373)^{1)}$ is shown in Fig. 3. It was observed that the behaviour of free CaM in healthy rice blades might reveal a pattern in normal growth and that the behaviour of free $\mathrm{CaM}$ in infected rice blade revealed the immediate decrease of free CaM down to about 0.05 units/g fresh weight 1 day after spray inoculation of blast fungus conidia.

\section{Effects of TPA on Both of the Parameters} The effects of TPA, potent activator on 


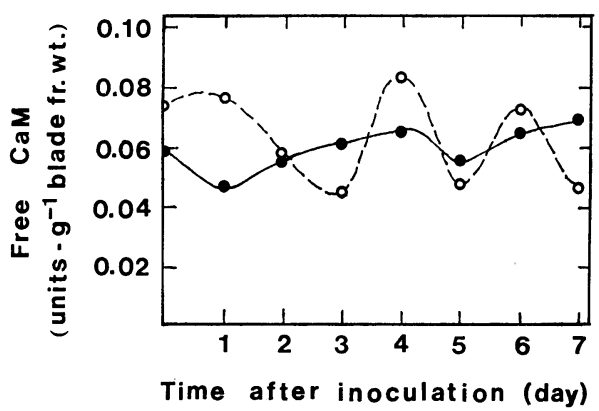

Fig. 3 Dynamic behaviour of free $\mathrm{CaM}$ in rice blade tissue inoculated with blast fungus conidia. The conidia of compatible blast fungus race (HOKU 373) was inoculated by usual spraymethod. As for coupled enzymatic analysis of CaM, see MATERIALS AND METHODS. O: healthy run, @: infected run. The similar behaviours were observed in duplicated experiments.
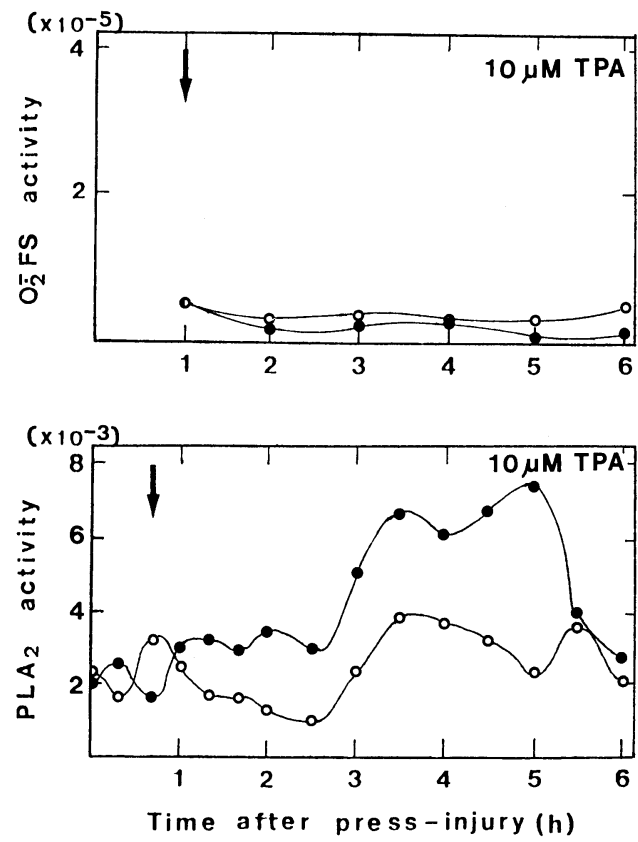

Fig. 4 Effects of TPA on $\mathrm{O}_{\dot{2}}^{-}$generation and $\alpha$ linolenate release from the press-injured rice blade tissue.

०: $2 \mathrm{~mm}$ press-injury with application of $5 \mu \mathrm{l}$ of $10 \mu \mathrm{M}$ TPA (control), 0 : application of TPA and additional stimulation by blast fungus elicitor. The arrow indicates the time of stimulation. The similar patterns were observed in duplicated measurements. proteinkinase $\mathrm{C}^{13-15)}$ on both the parameters are shown in Fig. 4. It was observed that TPA $(10 \mu \mathrm{M})$ did not activate the $\mathrm{O}_{2}^{-}$generation even after elicitor stimulation and that TPA $(10 \mu \mathrm{M})$ inhibited $\alpha$-linolenate release at the earlier phase but markedly activated $\alpha$ linolenate release at the later phase with elicitor stimulation.

\section{Effects of $H-7$ and Staurosporine on Both of the Parameters}

The effects of $\mathrm{H}-7$ or staurosporine, unspecific inhibitors on proteinkinases, ${ }^{16-19)}$ on both the parameters are respectively shown in Figs. 5 and 6 . It was observed that $\mathrm{H}-7$ ( $1 \mathrm{~mm})$ and staurosporine $(100 \mu \mathrm{M})$ inhibited $\mathrm{O}_{\dot{3}}^{-}$generation after elicitor stimulation, that staurosporine $(50 \mu \mathrm{M})$ rather activated $\alpha$-linolenate release at the later phase after elicitor stimula-
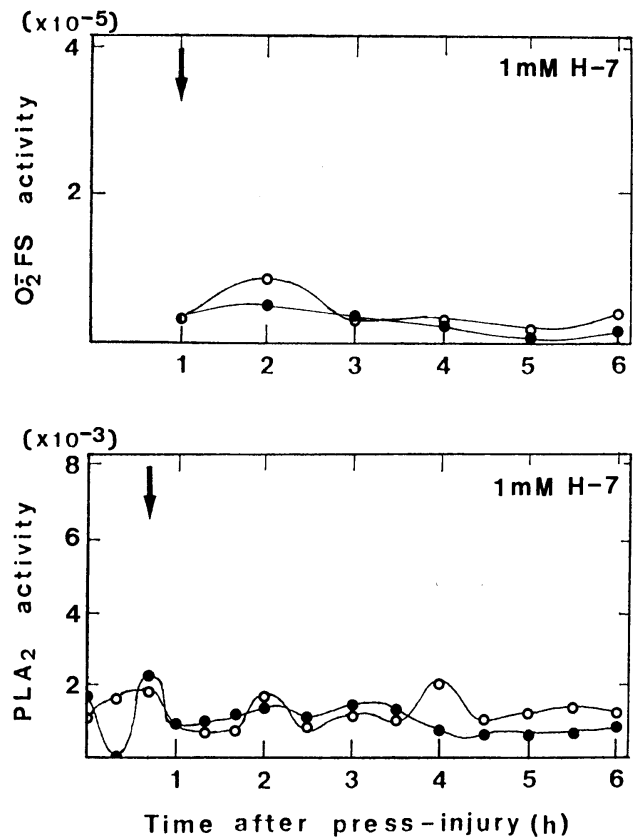

Fig. 5 Effects of $\mathrm{H}-7$ on $\mathrm{O}_{\dot{2}}^{-}$generation and $\alpha$ linolenate release from the press-injured rice blade tissue.

o: $2 \mathrm{~mm}$ press-injury with application of $5 \mu \mathrm{l}$ of $1 \mathrm{~mm} \mathrm{H}-7$ (control), application of $\mathrm{H}-7$ and additional stimulation by blast fungus elicitor. The arrow indicates the time of stimulation. The similar patterns were observed in duplicated measurements. 

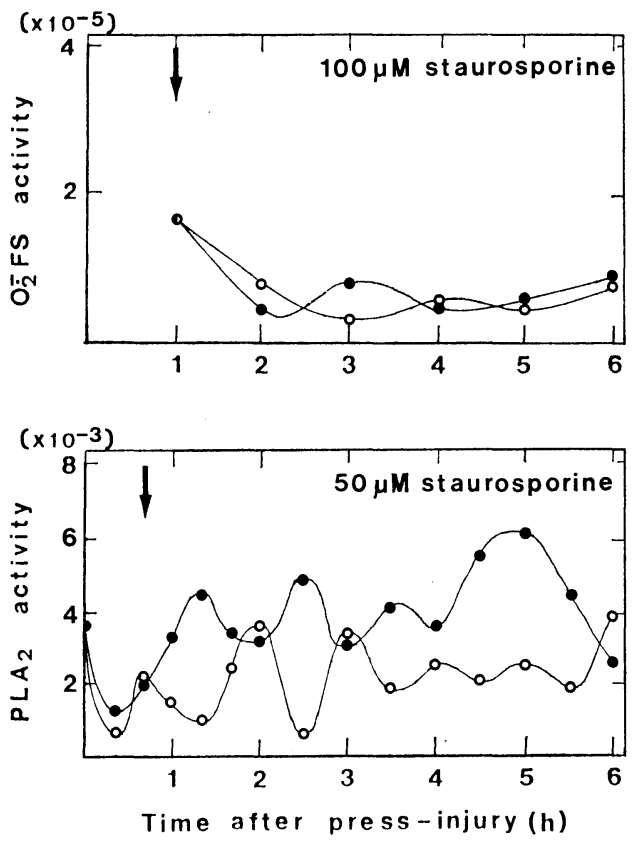

Fig. 6 Effects of staurosporine on $\mathrm{O}_{\dot{2}}^{-}$generation and $\alpha$-linolenate release from the pressinjured rice blade tissue.

o: $2 \mathrm{~mm}$ press-injury with application of $5 \mu \mathrm{l}$ of $100 \mu \mathrm{M}$ or $50 \mu \mathrm{M}$ saturosporine (control), application of staurosporine and additional stimulation by blast fungus elicitor. The arrow indicates the time of stimulation. The similar patterns were also observed in duplicated measurements.

tion, and that $\mathrm{H}-7 \quad(1 \mathrm{~mm})$ inhibited $\alpha$ linolenate release after elicitor stimulation.

\section{Effects of $S A C \cdot N a$ on Both of the $\mathrm{Pa}$ - rameters}

The effects of SAC $\cdot \mathrm{Na}$, an activator on the $\mathrm{O}_{\dot{2}}^{-}$generation from rice blade tissue infected by blast fungus, ${ }^{20,21)}$ on both the parameters are shown in Fig. 7. It was observed that $\mathrm{SAC} \cdot \mathrm{Na}(1 \mathrm{~mm})$ alone gave an moderate activation on $\mathrm{O}_{2}^{-}$generation at earlier phase when applied to the press-injured spots, and that elicitor stimulation further activated and shifted the $\mathrm{O}_{\dot{2}}^{-}$generation towards the earlier phase. It was also observed that $\mathrm{SAC} \cdot \mathrm{Na}$ ( $1 \mathrm{~mm}$ ) alone might slightly activated that $\alpha$ linolenate release, and that the elicitor stimulation markedly activated the release at the
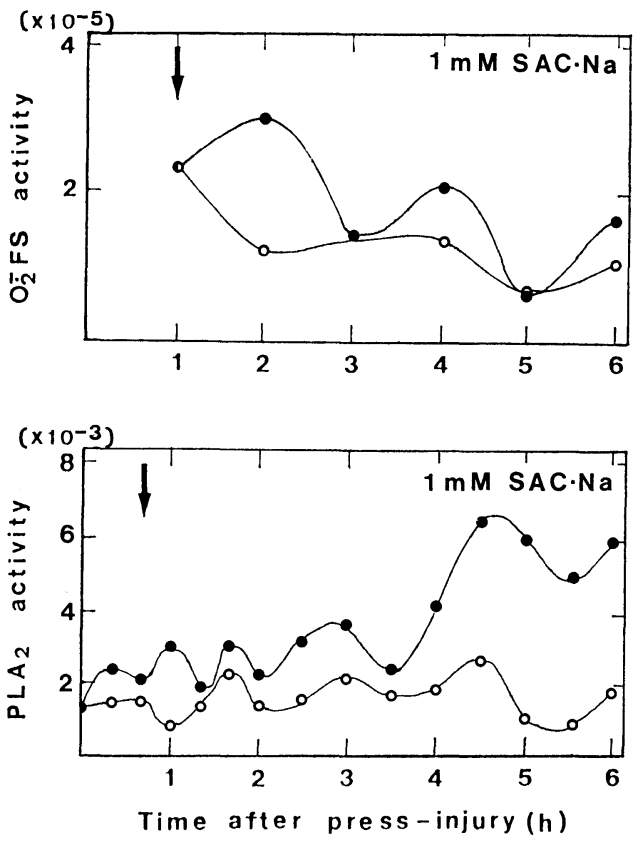

Fig. 7 Effects of $\mathrm{SAC} \cdot \mathrm{Na}$ on $\mathrm{O}_{\dot{2}}^{-}$generation and $\alpha$-linolenate release from the press-injured rice blade tissue.

$0: 2 \mathrm{~mm}$ press-injury with application of $5 \mu \mathrm{l}$ of $1 \mathrm{~mm} \mathrm{SAC} \cdot \mathrm{Na}$ (control), $\bullet$ : application of SAC. $\mathrm{Na}$ and additional stimulation. The similar patterns were observed in duplicated measurements.

later phase (Fig. 1A and $1 \mathrm{~B}$ in Part XII ${ }^{1)}$ ).

\section{DISCUSSION}

Using press-injured rice blade tissue stimulated by purified blast fungus elicitor, ${ }^{1}$ the relationships between $\mathrm{Ca}^{2+}$ as the second messenger and the activation of two parameters, the $\mathrm{O}_{2}^{-\overline{1}}$ generation and $\alpha$-linolenate release, were surveyed.

Both W-7 $(10 \mu \mathrm{M})$ and ophiobolin A $(10 \mu \mathrm{M})$, potent inhibitors on a function of $\mathrm{CaM},{ }^{8-10)}$ strongly inhibited the signal-coupled $\mathrm{O}_{2}^{-}$genneration (Figs. 1 and 2). The free CaM $(0.03$ units $/ \mathrm{g}$ fresh weight; $7.5 \%$ of total $\mathrm{CaM}$ ) of rice blade tissue decreased 1 day after spray inoculation of blast fungus conidia (Fig. 3). This revealed that free CaM was mobilized to form $\mathrm{Ca}^{2+} \mathrm{CaM}$ by blast fungus infection. Both W-7 $(500 \mu \mathrm{M})$ and ophiobolin A $(500 \mu \mathrm{M})$ also strongly inhibited the signal-coupled $\alpha$ - 
linolenate release (Figs. 1 and 2). The presence of plant $\mathrm{CaM}^{22)}$ and $\mathrm{Ca}^{2+}{ }_{-} \mathrm{CaM}$ dependent proteinkinase linked with the activation of phospholipase in potato leaves have been reported. ${ }^{23)}$ The lines of evidence indicated that both activation of $\mathrm{O}_{2}^{-}$forming redox system and phospholipase $A_{2}$ in elicitor-stimulated rice blade cells are strongly dependent on the formation of $\mathrm{Ca}^{2+}-\mathrm{MP}\left(\mathrm{Ca}^{2+}\right.$-calcium modulated protein), which includes $\mathrm{Ca}^{2+}-\mathrm{CaM}$ and/or $\mathrm{Ca}^{2+}$ CDPK ( $\mathrm{Ca}^{2+}$ dependent proteinkinase). ${ }^{24)}$

TPA $(10 \mu \mathrm{M})$ potent activator on protein kinase $\mathrm{C}^{13-15}$ ) inhibited both the $\mathrm{O}_{i}^{-}$generation and $\alpha$-linolenate release at earlier phase after elicitor stimulation (Fig. 4), suggesting that proteinkinase $\mathrm{C}$ might not participate in the activation of rice blade $\mathrm{O}_{2}^{-}$forming redox system and phospholipase $\mathrm{A}_{2}$ at earlier phase after elicitor stimulation. And both H-7 (1 $\mathrm{mm})$ and staurosporine $(100 \mu \mathrm{M})$, unspecific inhibitors on proteinkinase, ${ }^{16-19)}$ inhibited the $\mathrm{O}_{i}^{-}$generation. And $\mathrm{H}-7 \quad(1 \mathrm{~mm})$ markedly inhibited $\alpha$-linolenate release, and staurosporine $(50 \mu \mathrm{M})$ moderately inhibited $\alpha$-linolenate release at earlier phase implying that the phosphorylation reactions might be involved in the activation of $\mathrm{O}_{2}^{-}$forming redox system and phospholipase $\mathrm{A}_{2}$ (Figs. 5 and 6). The lines of evidence revealed that both the activations of $\mathrm{O}_{2}^{-}$forming redox system and phospholipase $\mathrm{A}_{2}$ of elicitor-stimulated rice blade cells are strongly dependent on $\mathrm{Ca}^{2+}$ CaM dependent proteinkinase and/or $\mathrm{Ca}^{2+}$ CDPK. ${ }^{23,24)}$ It has been reported that the activity of Dunaliella-CDPK is inhibited by relatively higher doses of CaM-inhibitors ${ }^{25)}$ and that soybean-CDPK has a regulatory domain which is $40 \%$ identical to plant calmodulin. ${ }^{26,27)}$

It was noted in this study that elicitorstimulated activation of phospholipase $A_{2}$ in rice blade cells was relatively insensitive to $\mathrm{Ca}^{2+}$ channel blockers (Fig. 7 in Part XII ${ }^{1)}$ ) and also to inhibitors on the formation of $\mathrm{Ca}^{2+}$ CaM (Figs. 1 and 2). It has been known that the formation of $\mathrm{Ca}^{2+} \mathrm{CDPK}$ is relatively insensitive to inhibitors on the formation of $\mathrm{Ca}^{2+}-\mathrm{CaM}^{25)}$ This bears out a hypothesis that the signal transduction system from opening of $\mathrm{Ca}^{2+}$ channel to activation of phospholipase $\mathrm{A}_{2}$ might utilize a molecular species of $\mathrm{Ca}^{2+}$-CDPK. As previously reported, ${ }^{1)}$ the presence of $\mathrm{Ca}^{2+}$ channel in rice blade cells, that was relatively insensitive to three blockers, was also indicated (Fig. 7 in Part $\left.X I^{1)}\right)$. Further studies are required to elucidate the presence and characteristics of $\mathrm{Ca}^{2+}$ channels and $\mathrm{Ca}^{2+}-\mathrm{MPs}$ participating in the coupling between the transmembrane signalling system and two intracellular signalling systems, which are thought to individually activate the two parameters used in this study, $\mathrm{O}_{2}^{-}$generation and phospholipase $\mathrm{A}_{2}$.

It was also noted in this study that TPA $(10 \mu \mathrm{M})$, an agonist of diacylglycerol, markedly activated the $\alpha$-linolenate release at the later phase after the elicitor stimulation (Fig. 4). The similar tendencies to the later activation were observed by the application of neomycin (1 mM), ${ }^{1)}$ an inhibitor on PI (phosphatidylinositol) turnover, or staurosporine $(50 \mu \mathrm{M})$, an inhibitor on proteinkinases (Fig. 6). Interestingly, the single applications of these three molecular probes also gave similar tendencies to the later activation (Fig. 2 in Part XII ${ }^{1)}$ and Figs. 4 and 6 in this report), although the correct explanation of these phenomena is not available at present. It has been reported that the activities of PI kinase and PIP (phosphatidylinositol 4-phosphate) kinase at plasma membrane of tobacco suspension culture cells are regulated by a negative feedback inhibition due to the increasing of cytosolic $\mathrm{Ca}^{2+}{ }^{28)}$ It has been reported that the signal-coupled activation of phospholipase $\mathrm{C}$ in animal cells is also indirectly regulated by a negative feedback inhibition due to the increase of diacylglycerol, ${ }^{13,15)}$ and that the presence of alternatively signal-activated phospholipase $\mathrm{A}_{2}$ system, which was positively regulated by the increase of diacylglycerol, is postulated. ${ }^{29,30)}$ When the presence of similar signal-activated phospholipase $\mathrm{A}_{2}$ system in rice blade cells, which was positively regulated by the negative feedback inhibition on PI turnover is hypothesized, the activation of phospholipase $\mathrm{A}_{2}$ at later phase without the operation of signalactivated phospholipase $\mathrm{C}$ system could be explainable, but a detail analysis concerned remains for future exploration.

$\mathrm{SAC} \cdot \mathrm{Na}(1 \mathrm{~mm})$ enhanced both the activa- 
tions of $\mathrm{O}_{\dot{-}}^{-}$forming redox system and phospholipase $\mathrm{A}_{2}$ (Fig. 7). Probenazole, 3-allyloxy1,2-benzisothiazole 1,1-dioxide, is a prodrug of $\mathrm{SAC}$, and is practically used as a priming effector to give a state of long-lasting systemic acquired-resistance against rice blast disease. ${ }^{31}$ ) It is noted that $\mathrm{SAC} \cdot \mathrm{Na}$ activates $\mathrm{O}_{\dot{2}}^{-}$forming redox system at very early phase and that it activates the rice blade phospholipase $A_{2}$ at the later phase after elicitor stimulation. This implies that the activation of phospholipase $\mathrm{A}_{2}$ at later phase is effective for the establishment of systemic acquired-resistance. The lines of evidence suggest that an action site of SAC exists within the transmembrane signalling and intracellular signalling systems to activate the two parameters and that the systemic distribution of $\mathrm{SAC}$ in rice blade cells give a state of systemic acquired resistance enhancing the signal-coupled activations of $\mathrm{O}_{\dot{2}}^{-}$forming redox system and phospholipase $\mathrm{A}_{2}$, which are subsequently linked to induction of a whole set of effective resistant reactions, immediately after blast fungus infection. ${ }^{1,20)}$ Very recently, it has been reported that a novel compound, $N$-cyanomethyl-2chloroisonicotinamide $(\mathrm{NCI})$, has the similar priming effect on probenazole enhancing the induction of lipoxygenase and peroxidase, when rice seedlings are treated with NCI via root system. ${ }^{32}$ Both chemical structures of $\mathrm{NCI}$ and $\mathrm{SAC}^{20}$ ) have common functional moieties, carbonylimide with individual electron drawing group such as 2-chloropyridinyl or sulfonyl group. An interesting evidence, which was obtained using NCI, is that NCI clearly activated PI turnover in elicitorstimulated rice-embryo culture cells. ${ }^{33)}$ This evidence and lines of evidence regarding signal transduction system of rice blade cells, which were described in the previous ${ }^{1)}$ and this report, bear out the suggestion that an actionsite of priming effectors like NCI and SAC, to give a state of long-lasting systemic acquired resistance, duly resides in the signal-activated phospholipase C system, although the detail regulatory mechanisms as for the activation of phospholipase $\mathrm{C}$ are still a matter of controvercy related to a signal-activated PIP kinase system and/or inhibitory constraint factor of phospholipase $C^{34,35)}$

\section{ACKNOWLEDGMENTS}

This work was supported by a Grant-in-Aid for Scientific Research 01480055 from Japanese Ministry of Education, Science and Culture.

\section{REFERENCES}

1) H. Kanoh, M. Haga, M. Iwata \& Y. Sekizawa: J. Pesticide Sci. 18, 299 (1993)

2) A. Tartakoff: TIBS 8, 117 (1983)

3) B. M. Babior: Arch. Biochem. Biophys. 264, 361 (1988)

4) W. M. Nauseef, B. D. Volpp, S. McCormik, K. G. Leidal \& R. A. Clark: J. Biol. Chem. 266, 5911 (1991)

5) J. Parker, L. W. Daniel \& M. Waite: J. Biol. Chem. 262, 5385 (1987)

6) M. Yazawa, M. Sakuma \& K. Yagi: J. Biochem. 87, 1313 (1980)

7) S. Shiefer: "Method of Enzymatic Analysis," ed. by $\mathrm{H}$. Bergmeyer, J. Bergmeyer \& M. Grassel, Vol. 9, VCH Publishers, Germany, pp. 317-331, 1986

8) H. Hidaka, Y. Sasaki, T. Tanaka, T. Endo, S. Ono, Y. Fujii \& T. Nagata: Proc. Natl. Acad. Sci. USA 78, 4354 (1981)

9) P. C. Leung, W. A. Taylor, J. H. Wang \& C. L. Tipton: J. Biol. Chem. 259, 2742 (1984)

10) P. C. Leung, W. A. Taylor, J. H. Wang \& C. L. Tipton: Plant Physiol. 77, 303 (1985)

11) S. Muto: Protein Nucleic Acid Enzyme 30, 217 (1987) (in Japanese)

12) H. Hidaka \& S. Kakiuchi: "Calmodulin-Ca ${ }^{2+}$ Recepting Protein," Kodansha Press, Tokyo, p. 27, 1981 (in Japanese)

13) M. Castagna, Y. Takai, K. Kaibuchi, K. Sano, U. Kikkawa \& Y. Nishizuka: J. Biol. Chem. 257, 7847 (1982)

14) Y. Nishizuka: Nature 334, 661 (1988)

15) J. Axelrod: Biochem. Soc. Trans. 18, 503 (1990)

16) M. Inagaki, S. Kawamoto \& H. Hidaka: $J$. Biol. Chem. 253, 14321 (1984)

17) S. Kawamoto \& H. Hidaka: Biochem. Biophys. Res. Commun. 125, 258 (1984)

18) T. Tamaoki, H. Nomoto, I. Takahashi, Y. Kato, M. Morimoto \& F. Tomita: Biochem. Biophys. Res. Commun. 135, 397 (1986)

19) H. Nakano, E. Kobayashi, I. Takahashi, T. Tamaoki, Y. Kuzuu \& H. Iba: J. Antibiot. XL, 706 (1987)

20) Y. Sekizawa, M. Haga, E. Hirabayashi, N. Takeuchi \& Y. Takino: Agric. Biol. Chem. 51, 763 (1987)

21) Y. Sekizawa, M. Haga \& H. Kanoh: Ann. Phytopathol. Soc. Jpn. 56, 565 (1990) 
22) R. A. Moreau: Dairy Sci. 70, 1504 (1986)

23) R. A. Moreau: Plant Sci. 47, 1 (1986)

24) D. M. Roberts \& A. C. Harmon: Ann. Rev. Plant Physiol. Mol. Biol. 43, 375 (1992)

25) T. Yuasa \& S. Muto: Arch. Biochem. Biophys. 296, 175 (1992)

26) C. Putnam-Evans, A. C. Harmon \& M. J. Cormier: Biochemistry 29, 2488 (1991)

27) J. F. Harper, M. R. Sussman, C. PutnamEvans, H. Charbonneau \& A. C. Harmon: Science 252, 951 (1991)

28) Y. Kamada \& S. Muto: Biochim. Biophys. Acta 1093, 72 (1991)

29) Y. Kajiyama, T. Murayama, Y. Kitamura, S. Imai \& Y. Nomura: Biochem. J. 270, 69 (1990)

30) M. Liscovith: TIBS 17, 393 (1992)

31) Y. Sekizawa \& S. Mase: Rev. Plant Prot. Res. Jpn. 13, 114 (1980)

32) K. Seguchi, M. Kurotaki, S. Sekido \& I. Yamaguchi: J. Pesticide Sci. 17, 107 (1992)

33) K. Seguchi, S. Sekido \& I. Yamaguchi: $J$. Pesticide Sci. 17, 123 (1992)

34) M. C. Pike, M. E. Brunck, C. Arndt \& Chi-Shen Lee: J. Biol. Chem. 265, 1866 (1990)

35) M. Camps, C. Hou, K. H. Jakobs \& P. Gierschik: Biochem. J. 271, 743 (1990)
要 約

イネいもち病菌エリシターで刺激したイネ葉身 細胞において作動する膜情報伝達系. II. カル シウム調節タンパク質の関与

加納大聖，芳賀 実，関沢泰治 前報に続き，イネ葉身細胞の膜情報伝達系に共役する $\mathrm{O}_{\dot{2}}^{-}$生成酸素系およびホスホリパーゼ $\mathrm{A}_{2}$ (本研究にお汭 る二つの指標）の活性化反応に係わる細胞内情報伝達系 を探査した．分子プローブとしてW-7，オフィオボリ ンA，TPA， H-7，およびスタウロスポリンなどを用 い，前報と同様の計画の下で探査を行ない， $\mathrm{Ca}^{2+}$ 調節 タンパク質 (CaM あるいは CDPK) が両指標の活性化 反応に重要な役割を果たすこと，プロテインキナーゼが 関与するなら $\mathrm{Ca}^{2+-} \mathrm{CaM}$ 依存性 プロテインキナーゼあ

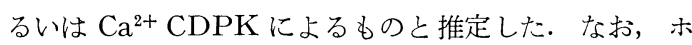
スホリパーゼ $\mathrm{A}_{2}$ の活性化反応の制御には末知の制御経 路が介在している可能性を推考した１,2-ベンッイソチ アゾール-3(2H)-オン 1,1-ジオキシドは早期相において $\mathrm{O}_{\dot{\mathrm{i}}}^{-}$生成を高進させ， $\alpha$-リノレン酸放出を後期相で著し く高進させた.プロベナゾールがプライミング効果剤と して付与する全身獲得抵抗性での両指標が，エリシター 刺激のみによる型と異なることが注目された．同様の機 能を有する NCI は PI ターンオーバを加速することが 最近報告されたので，前報および本報による知見ととも に，総合考察し，この種の非殺菌性防除剤の作用部位は イネ葉身細胞の膜情報伝達系（ホスホリパーゼ C 系）に 存在すると推定された.

*イネの誘導防御機構における反応カスケードの因果 律に関する研究 (第 13 報) 